\title{
Comparing the socialist rural architecture of the Baltic States: the past and the future of the administrative-cultural centres of collective farms.
}

\author{
Laura Ingerpuu ${ }^{1,1}$ \\ ${ }^{1}$ Estonian Academy of Arts, Cultural Heritage and Conservation, Tallinn, Estonia
}

\begin{abstract}
Collectivisation of agriculture in Estonia, Latvia and Lithuania was a drastic change that shaped rural built landscapes of the Baltic countries for five decades. Although Estonia, Latvia and Lithuania have been independent states, and collective farming has been abolished for almost thirty years now, the physical legacy of collective farms still exists. This paper examines what are the present processes in terms of preservation and valorisation of collective farm architectural heritage in the Baltic States. The focus of the analysis is on the administrativecultural buildings of the collective farms, built between the 1960s and 1990s, which represent the modernist and postmodernist rural architectural gems. I compare the context of the establishment of the administrative-cultural centres in Estonia, Latvia and Lithuania as well as developments in reuse and protection of these buildings after the abolishment of collective farming. I also analyse today's situation in terms of acceptance of this socialist legacy as a meaningful part of the history. My study is based on the field work in the relevant countries, available literature and data, and interviews conducted with the heritage conservation experts and researchers in this field.
\end{abstract}

\section{Introduction}

Agricultural collectivisation was forcibly implemented by the authorities of the Soviet Union in all the occupied Baltic Republics at the end of the 1940s. Since the idea of collectivisation was to implement large-scale and industrialised agricultural production, and at the same time to concentrate rural population into central collective farm settlements with all city-like comforts and infrastructure, massive construction work began in the countryside. This meant a change of the entire physical environment of rural areas. The most intensive period of rural construction was in the 1970s and 1980s when the collective farms (kolkhozes and sovhozes) ${ }^{2}$ were quite prosperous and life in

\footnotetext{
${ }^{1}$ Corresponding author: laura.ingerpuu@artun.ee

2 Kolkhozes and sovhozes were both state-controlled entities based on collective farming, however kolhozes did not belong to the state and they operated under registered statute. Although the word 'kolkhoze' comes from the Russian word 'колхоз' meaning 'collective farm' and 'sovhoze' could be translated as 'state farm', both of the cooperatives are in the literature, as well as in everyday talk, predominantly called with the common term 'collective farm'.
} 
the countryside was blossoming. However, it all ended at the beginning of the 1990s, together with the re-establishment of independence of the Baltic States, when private farming was restored and collective farms were closed down. Nevertheless, more than two decades after the abolition of collective farming, the built legacy of the era is present in the rural areas of Estonia, Latvia and Lithuania and it cannot be ignored nor can it be erased from the landscape. Moreover, there are many architectural masterpieces of the time that deserve to be valued and preserved in the context of today's heritage conservation policies.

My research is focused on the administrative-cultural centres of the collective farms. I am particularly interested in the buildings designed and erected between the 1960s and the beginning of the 1990s because it was the time of the modernism and postmodernism in Baltic rural architecture, which went hand in hand with the creation of unique construction. I am referring to these edifices as administrative-cultural centres since they were mainly a combination of an office and a cultural-club house, although they often included other functions, such as a library, canteen, bank, cinema, etc. as well. Since the general construction policies were very much alike in the Baltic States and similar type of administrative-cultural centres were built in all the Baltic collective farms, it is relevant to study them in comparison.

Today, Estonian, Latvian and Lithuanian rural areas and former collective farm settlements face similar socio-economic issues which do not support the preservation and reuse of the collective farm built heritage. That is why I am analysing the current situation regarding the preservation, regeneration and protection of these edifices from the heritage conservation perspective. I am also studying the aspects of why these buildings are valuable and to whom they matter. Although, the total amount of information gathered for this study in Latvia and Lithuania via field work and through interviews with experts in the field is not as large as for Estonia, some similarities and differences can be outlined and conclusions can be drawn.

\section{The heyday and downfall of the administrative-cultural buildings of collective farms}

The heyday of the administrative-cultural buildings of collective farms began together with the political and economic changes at the level of the whole Soviet Union. Due to Khrushchev's liberal reforms at the end of the 1950s, Baltic agriculture also recovered from the economic slump caused by collectivisation. Already, by the end of the 1960s collective farms became quite prosperous due to the high demand for agricultural products in the Soviet Russian market. This also meant an increase in living standards, construction capacities and ambitions that consequently influenced the construction of public buildings. Another aspect that affected construction works in the Baltic States, was Khrushchev's well-known speech in 1954 to the All-Union Conference of Soviet Builders, Architects and Workers in the Building Materials Industry, which ended Stalinism in architecture and laid the foundation for rational industrialisation and modernisation of construction [1]. Although the main focus was on the massive housing construction, the speech also opened up opportunities to explore ideas from outside the Union and encouraged a new generation of Baltic architects to find the ways to create something different in the prevailing mass production environment. Characteristic feature of post-war modernism, which arrived with a delay in Soviet Baltic Republics, was that the ideas obtained from the West, mainly from the Nordic countries, were frequently combined with national routes and traditions [2, 3, 4]. Architecture of the palace of culture of the Fishing 
Kolkhoz Zvejnieks in Latvia, built in 1956, for example, is a particular example of the period of transition from Stalinism to modernism [5] (Fig. 1).

While the bulk of constructions, mostly dwellings, were still built according to standard projects throughout the entire Soviet-era, a number of public buildings were erected on the basis of individual projects. The administrative-cultural buildings most frequently had the privilege of being built through a unique design. For example, in Estonia, the State Construction Committee of Soviet Estonia declared that the office buildings of collective farms could be exceptionally built according to single designs to comply with their multi-functionality and to emphasise the regional peculiarities [6]. One of the avant-garde collective farm offices in Estonia was the administrative building of Kurtna Experimental Poultry Farm, which was completed in 1966. The novel and "western" design of this building was the beginning of fame for the new rural architecture in Soviet Estonia [7]. At the same time, in Lithuania, in the 1960s as well as in the 1970s, standard planning was still quite common even for cultural centres which were supposed to be among the most representative buildings of all the collective farm constructions. For example, the Leonpolis experimental collective farm settlement was impressive due to its homogeneous urban environment but the administrative-cultural centre itself was nothing else than a rectangular box [8]. In Latvia, construction of administrative-cultural houses through individual projects was more broadly implemented from the second half of the 1970s, when the pressure to bring more diversity into the collective farm constructions, while paying more attention to the environment as a whole, increased [9, 10]. To name one among many others - the office-club building in Nigrande, in Saldus district was designed as a hallmark of the area [10].

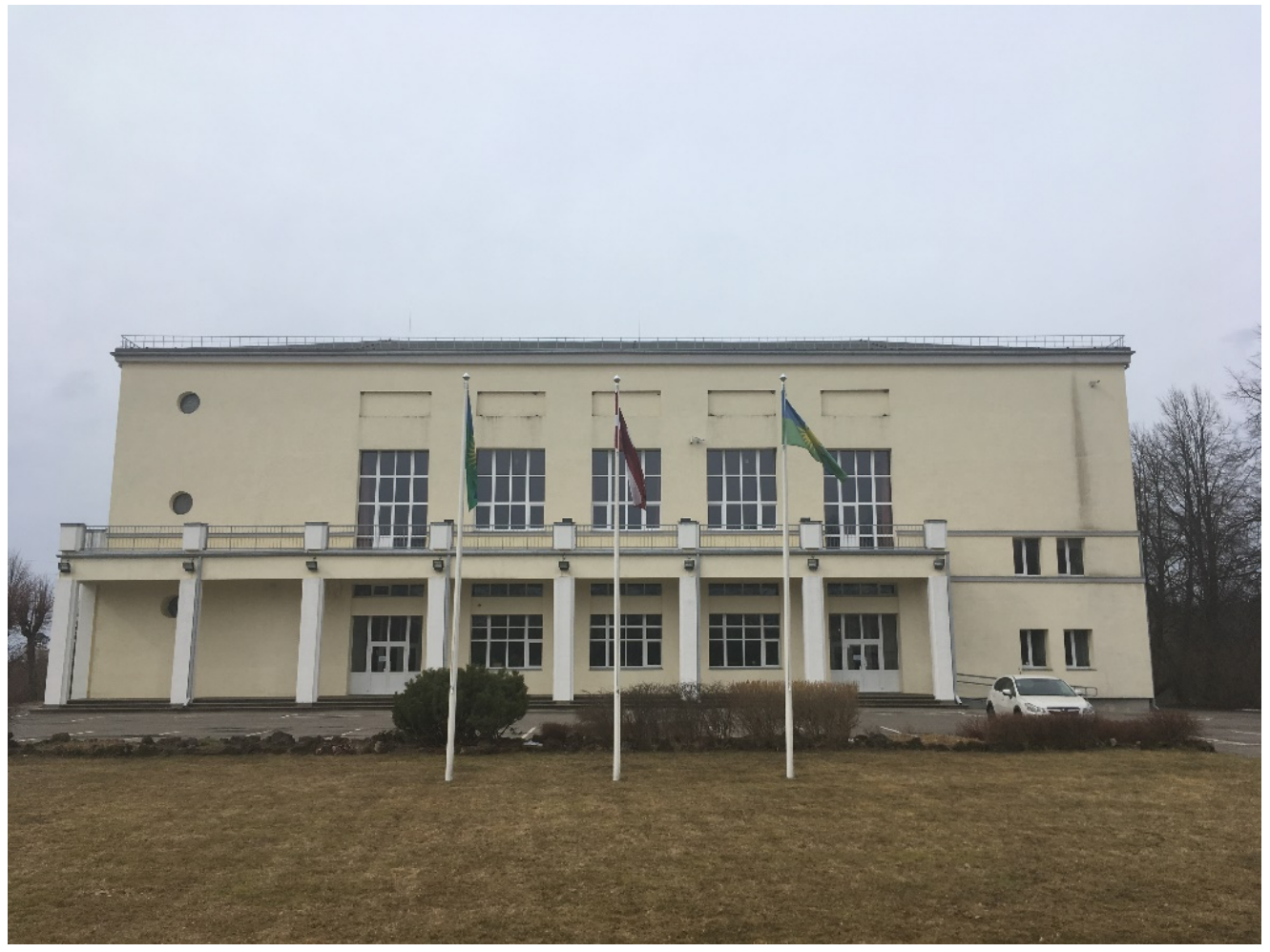

Fig. 1. The palace of culture of the Fishing Kolkhoz Zvejnieks in Latvia, architect: Marta Stana, built in 1956. Photo: Laura Ingerpuu, 2018. 


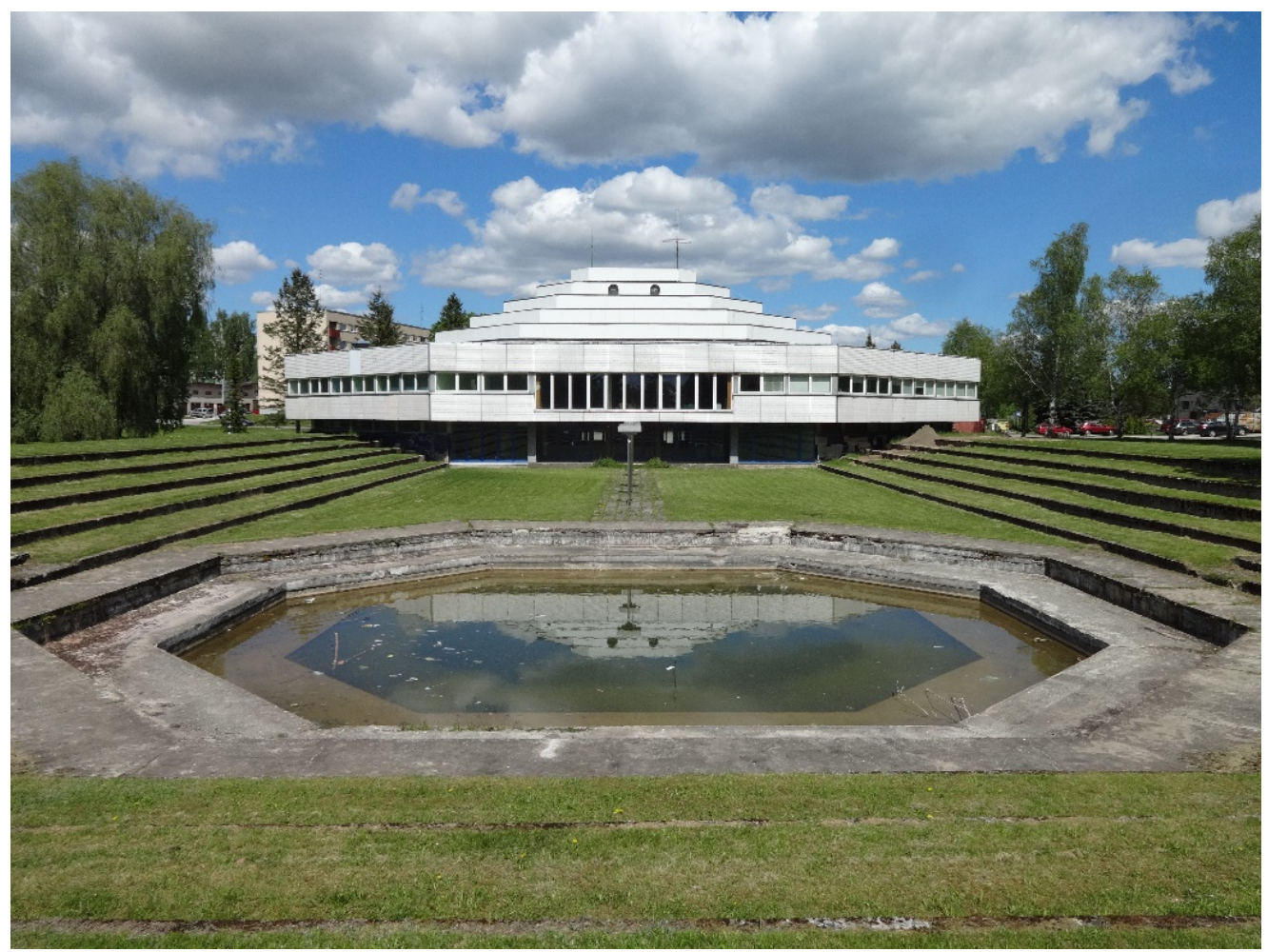

Fig. 2. The administrative building of Rapla Collective Farm Construction Office in Estonia, architect Toomas Rein, built in 1977. Photo: Laura Ingerpuu: 2017.

Compared to Latvia and Lithuania, a separate phenomenon in Estonia was the establishment of the inter-collective farm construction offices, which were created by kolkhozes already at the end of 1950s to implement the construction works in the region. The inter-collective farm construction offices belonged to the kolkhozes and were built according to their instructions; however, in the 1970s they became rather independent and began to implement their own ambitions [11]. Therefore, some of the most exceptional administrative buildings built in Estonia were actually built by the intercollective farm construction offices for their own management. For example, the office of the Rapla Collective Farm Construction Office is considered to be one of the most extraordinary Soviet-era administrative buildings today [12] (Fig. 2).

Another aspect that made the administrative-cultural centres exceptional was the synthesis of art and a homogenous combination of exterior and interior architectural elements, which was common for the buildings built through unique design. We can find there many outstanding wall paintings, murals and stained glass in the halls and on the exterior walls of many of the administrative-cultural centres. To name but two - the mural created by $M$. Mačiulienè on the façade of the administrative-cultural building of Draugas Kolkhoz, in Lithuania (Fig. 3), and a wall painting designed by Eeva-Aet Jänes in the administrative building of Põdrangu Sovhoz, in Estonia. Therefore, many of those buildings were the masterpieces of the local young and talented architects and interior designers. The Baltic collective farm settlements as ensembles as well as the single administrative-cultural buildings were also awarded in the Union-wide and local architectural competitions. The original integral solutions of the collective farm settlements as well as the prominence of the single buildings crossed even the borders of the Soviet Union and were many times reflected in the Western media. 


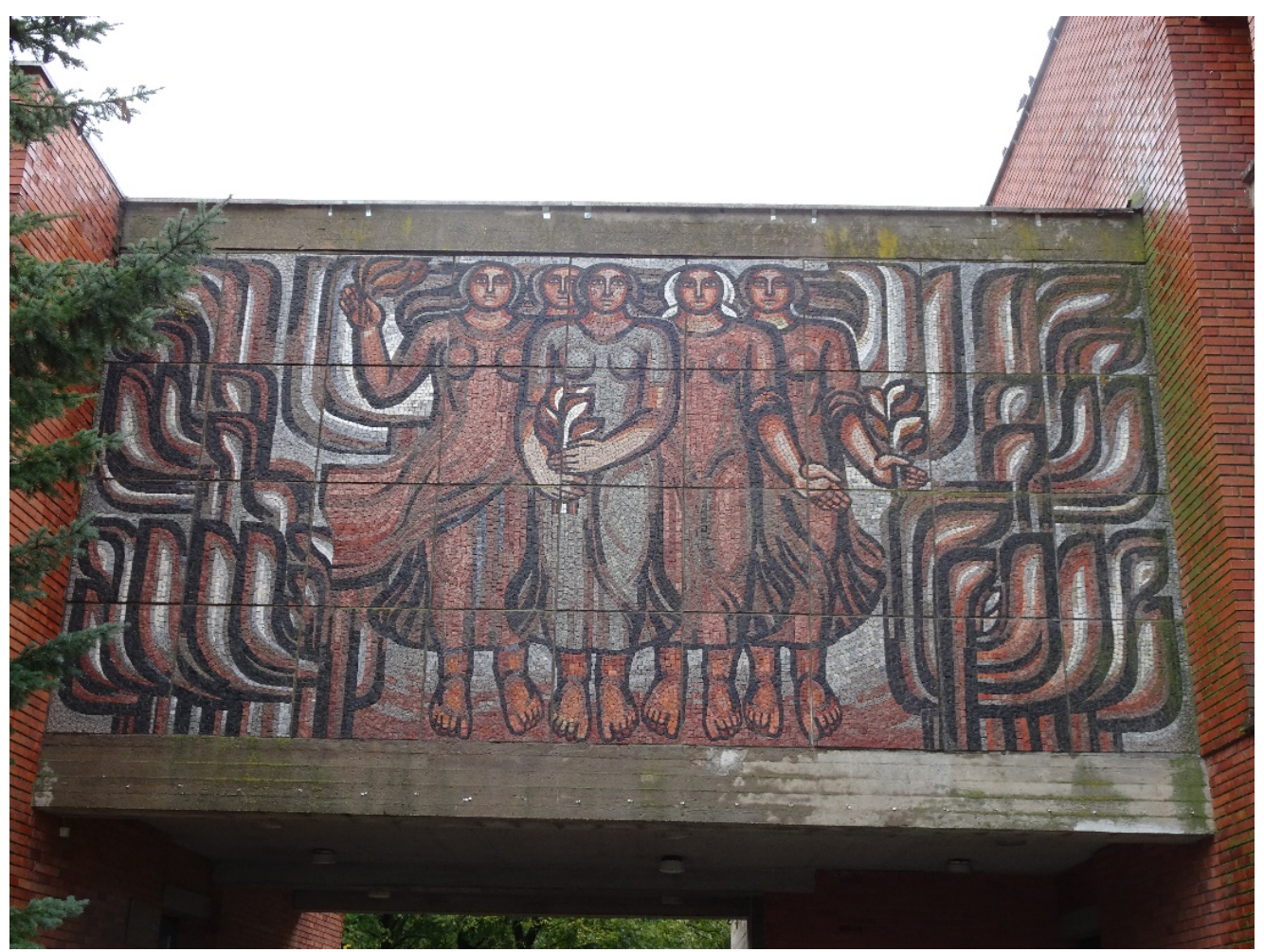

Fig. 3. Mural on the façade of the administrative-cultural building of Draugas Kolkhoz in Lithuania, designed BY M. Mačiulienè. Photo: Laura Ingerpuu, 2017.

The period of the 1970s and 1980s was equally prosperous for the collective farms in all the Baltic States, when the living conditions in the countryside were rather good, the rural population was increasing, and the community centres were in active use by the local people. However, it all ended together with the collapse of the Soviet regime. Abolition of collective farming led to the abandonment of collective farm settlements since the rural population began to decrease rapidly and the overall living standards in the countryside stagnated compared to the urban areas. Together with the socioeconomic changes in the countryside, a new function had to be found for the former collective farm administrative-cultural centres. The fate of these buildings depended on the wealth and demographic developments of the specific region or village as well as on the new owner. The ones that remained in public use were usually used as municipality buildings, libraries or community and cultural houses, which meant that they were maintained or repaired at least to a minimal level. The privately owned edifices were more often abandoned if a suitable new function was not found for them. However, there are exceptions, for example the administrative building of kolkhoz "Kalevipoeg" in Estonia, which the owner converted into his farm house (Figure 4). There are also a number of former outstanding buildings in all the Baltic States that have already become ruins. 


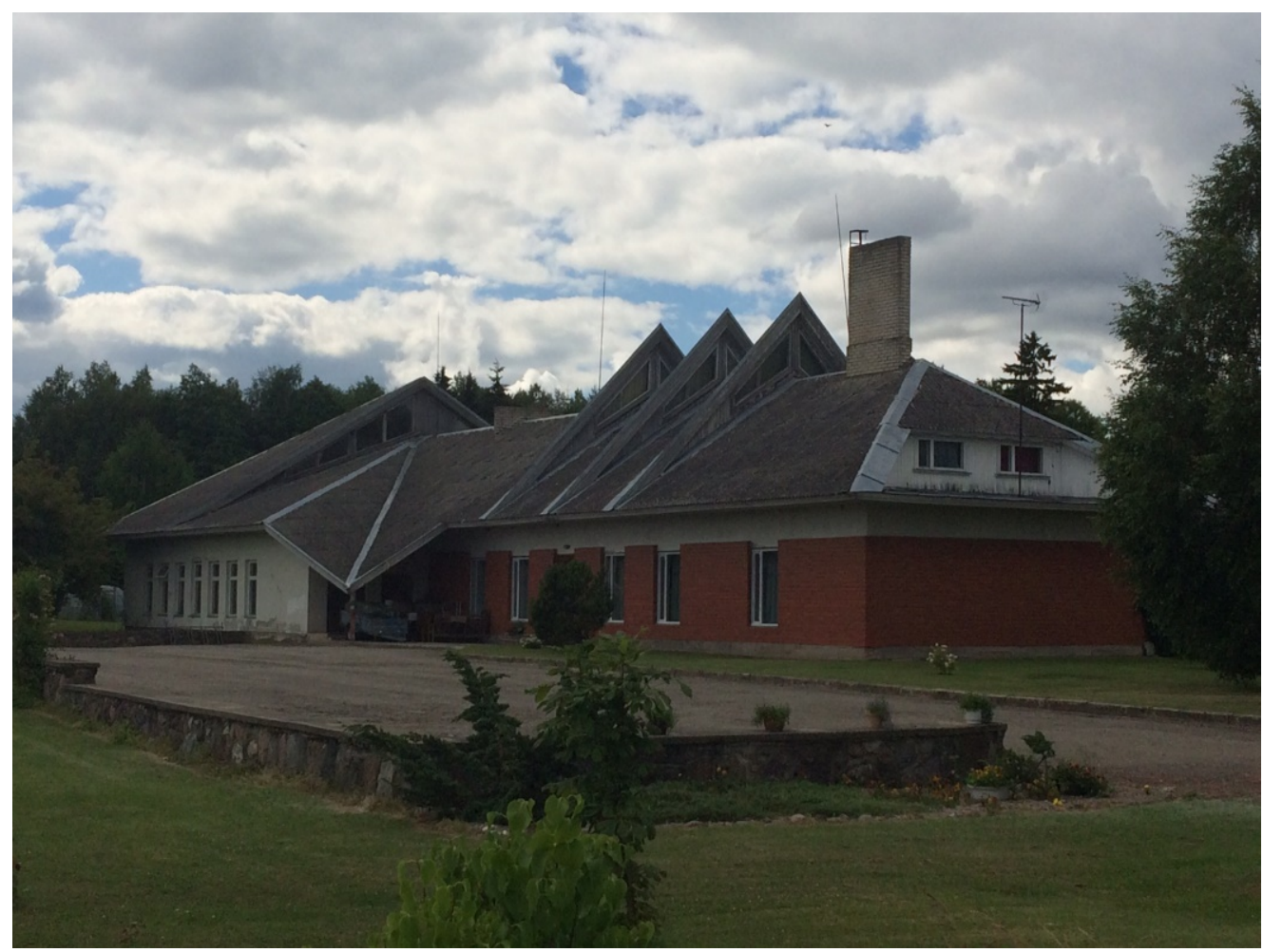

Fig. 4. The administrative building of kolkhoz "Kalevipoeg" in Estonia, architect unknown, built in the 1980s, which is reused as a farm house. Photo: Laura Ingerpuu, 2017.

\section{Today's developments and assessments}

In the 1990s, the Soviet-era architecture was still relatively young and as people commonly do not perceive the buildings of their own time as heritage, the architecturalhistoric values of the objects from this era were not yet perceived. Additionally, in the first years of the newly independent Baltic States, an overwhelming hatred towards everything originating from the Soviet time prevailed. Architectural and art historians, and other experts in the field have explored the architecture from the Soviet-era well before the general public began to pay attention to it. Today there are already a number of Soviet-era buildings, Stalinist as well as modernist architecture, listed as national monuments in Estonia, Latvia and Lithuania. However, the main focus of research or of national protection is on the socialist architecture in the bigger cities, while the countryside has been neglected everywhere.

Therefore, it could be said that Estonia has been at the forefront in studying and mapping the most outstanding pieces of Soviet-era rural architecture, since between 2008 and 2012 the project of "Mapping and analysing Estonian $20^{\text {th }}$ century (1870-1991) valuable architecture" was carried out ${ }^{3}$. The project, executed by researchers, focused

3 Eesti 20. sajandi (1870-1991) väärtusliku arhitektuuri kaardistamine ja analüüs (https://www.artun.ee/eesti-20-sajandi-1870-1991-vaartusliku-arhitektuuri-kaardistamine-jaanaluus/) was conducted by the Estonian Academy of Arts Heritage Conservation and Restoration Department in partnership with the Ministry of Culture, National Heritage Board . The registry can be consulted (in Estonian), on the online National Register of Cultural Monuments (https://register.muinas.ee/public.php?menulD=architecture). 
on the architecture of the entire $20^{\text {th }}$ century, thus it involved a thorough research of the Soviet period, including collective farm architecture. This research is a good basis for the listing decisions for the Estonian National Heritage Board now. Today, there are three administrative buildings of collective farms listed as architectural monuments in Estonia - the main building of the Kurtna Experimental Poultry Farm, listed in 2001; the administrative building of the Saare Collective Farm Construction Office, listed in 2004; and the administrative building of the Rapla Collective Farm Construction Office, listed in 2015. Also, the administrative-cultural centre of Linda Kolkhoz (Fig. 5) is in the queue for listing in the near future.

In 2009, the Lithuanian Union of Architects also created a list of the most outstanding modernist buildings; however, it did not include academic research and was not officially used by the Heritage Department $[13,14]$. At the moment, in Lithuania, there is only one collective farm, the former Jucnaičiai Sovhoz, included into the list of national heritage. Thus, it is listed as an entire complex due to its urbanistic and landscape design and not as individual buildings [15]. In Latvia, the more thorough research on the $20^{\text {th }}$ century modernist architecture was conducted in 2014 for the catalogue of the Latvian Exhibition at the $14^{\text {th }}$ International Architecture Exhibition - la Biennale di Venezia, which was composed by Latvian architects [16]. This is also the base for listing decisions for the Latvian Heritage Inspection; however, it does not include collective farm architecture and there are no administrative-cultural buildings of collective farms listed in Latvia so far. Also in Latvia as well as in Lithuania the administrative-cultural centres of the collective farms are not particularly well-studied for the purpose of being taken under national protection at the moment $[17,18]$.

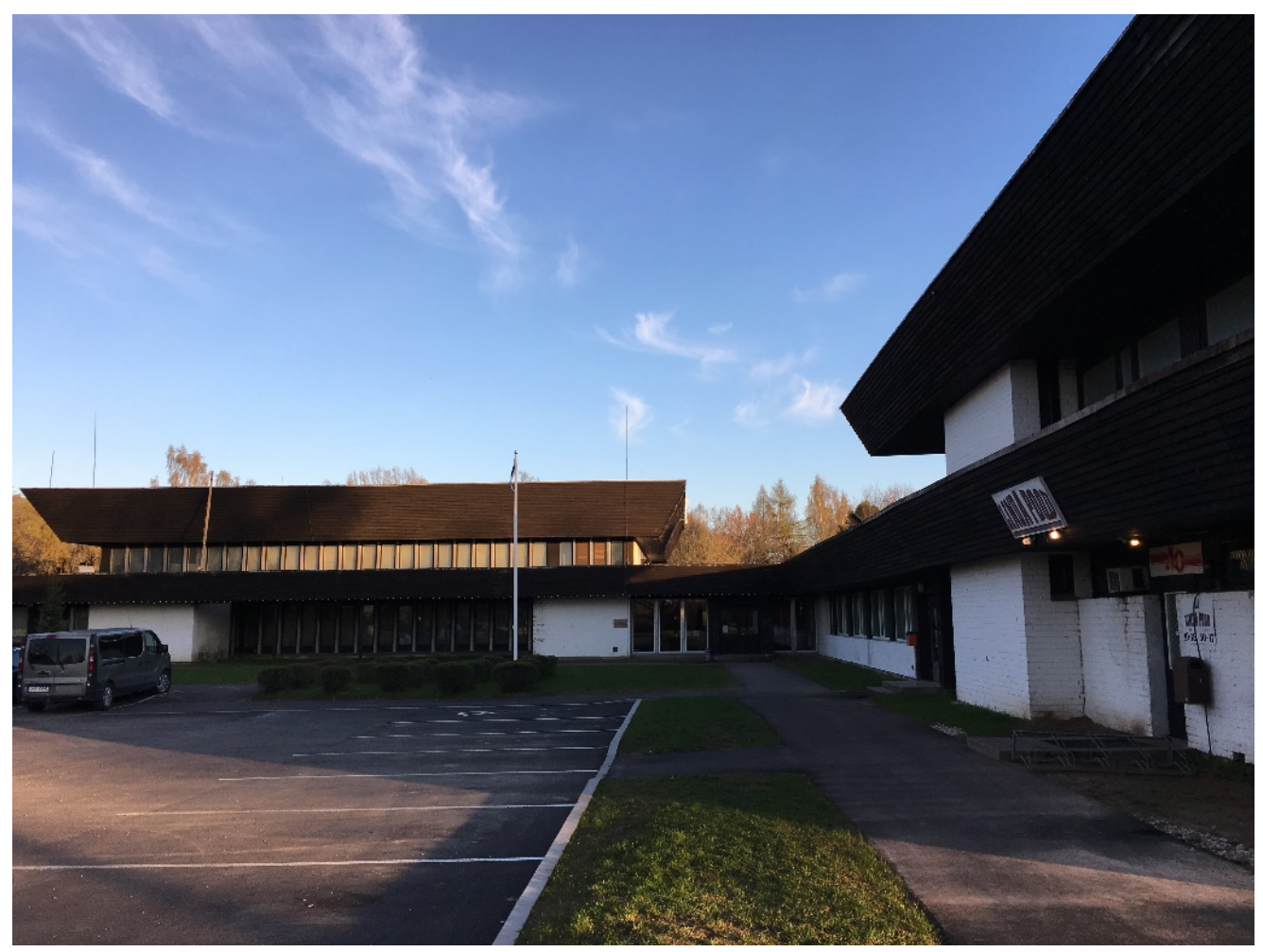

Fig. 5. The administrative building of kolkhoz "Linda" in Estonia, architect Toomas Rein, built in 1969-1973. Photo: Ingerpuu, 2018. 
Nevertheless, evaluation of the collective farm architecture at the national level is just one aspect in preserving this heritage; no less important is the attitude of the "ordinary" people and the local community. For example, in Lithuania, where the socialist architecture in general is in the focus of the Lithuanian Heritage Department, protecting and listing of the Soviet-era objects has become quite complicated due to the public opinion which, after the occupation of Crimea by Russia in 2014, has been aggressive towards everything resembling Soviet-era [18]. This shows that the mindset of the 1990s is still dominant for the Lithuanians. Similarly, attitudes devaluing the era as a whole and not the architecture itself, have not disappeared from the minds of the public in Estonia and Latvia either. Nevertheless, a negative attitude towards the former administrative-cultural buildings of collective farms is most of all attached to the technical state of the buildings. When a building is in use and well maintained, it is perceived quite well, but a building which is in a bad technical condition is mainly seen as rubbish. This is the frequent opinion in Estonia as well as in Latvia and Lithuania [10, $13,19]$. During my visits to different collective farm settlements, I also met some local activists, mainly from the cultural sector, who are very much interested in preserving the local collective farm built heritage. For example, the director of the cultural house in Alksniupiai in Lithuania, introduced with shining eyes the local collective farm history and the museum of Draugas Kolkhoz, which is established in the former administrativecultural centre of Draugas collective farm. Nevertheless, the enthusiasm of these people is not enough to solve the socio-economic issues in the countryside that affect the survival of those buildings.

Therefore, the main immediate reason for non-functioning or decay of the former administrative-cultural buildings is still the socio-economic situation of rural areas in all the Baltic States, especially in the most remote regions, away from the main centres. Since most of these buildings have rather large volumes, which was relevant during the period of collective farms but became unreasonable in the light of a decreasing rural population, finding a proper new function is challenging. The general picture is rather comparable in Estonia, Latvia and Lithuania: the most remote areas are usually in the worst situation, where the former collective farm settlements are emptied of people, the population is ageing, many houses are abandoned, and the public buildings urgently need to be repaired. In every country, there can be found some former gems that have become ruins and a landscape littered with decaying objects. For example, the administrative building of Tsooru Kolkhoz in Estonia, the administrative and cultural house of Kirov Kolkhoz in Lithuania, and the administrative building of Renda Kolkhoz in Latvia are all buildings which were masterpieces of time that were presented in many of the Soviet time architectural publications $[9,20,21]$ (Fig. 6).

Latvia stands out for with one peculiarity - since the construction of a number of administrative-cultural buildings began at the end of the 1980s, they were never completed due to the political and economic changes at the beginning of the 1990s. Therefore, there can be found impressive postmodernist colossi in completely remote areas in Latvia which are abandoned, unused and already falling apart. For example, the administrative-cultural building in Nigrande (Fig. 7). So, the sadness lies in the fact that the buildings which were admired and important in their own time have become useless and disturbing objects today. And since being abandoned for many years now, they might disappear completely in the future. 


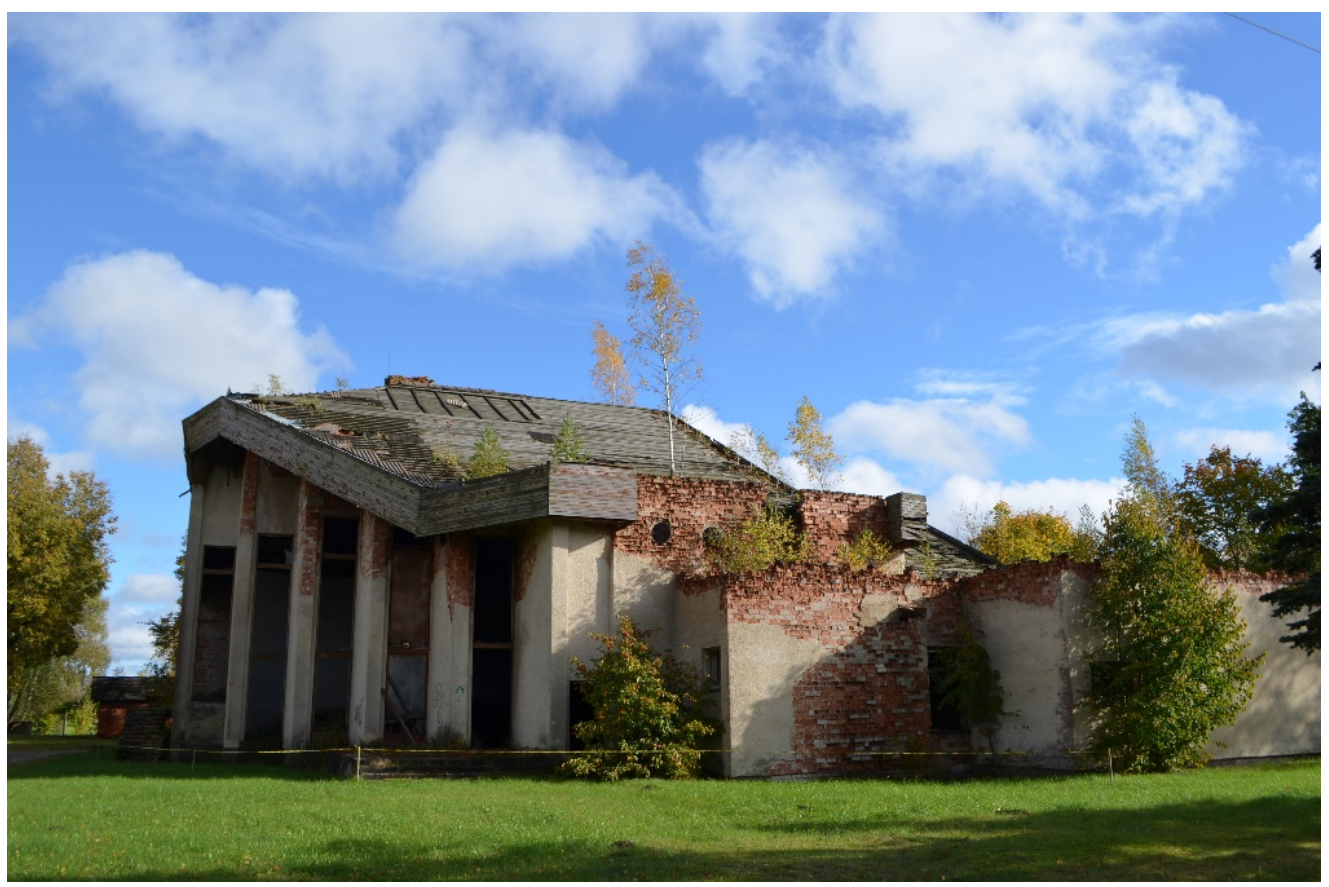

Fig. 6. The administrative-cultural building of Kirov Kolkhoz in Lithuania, architect P. Adomaitis. Photo: Laura Ingerpuu, 2017.

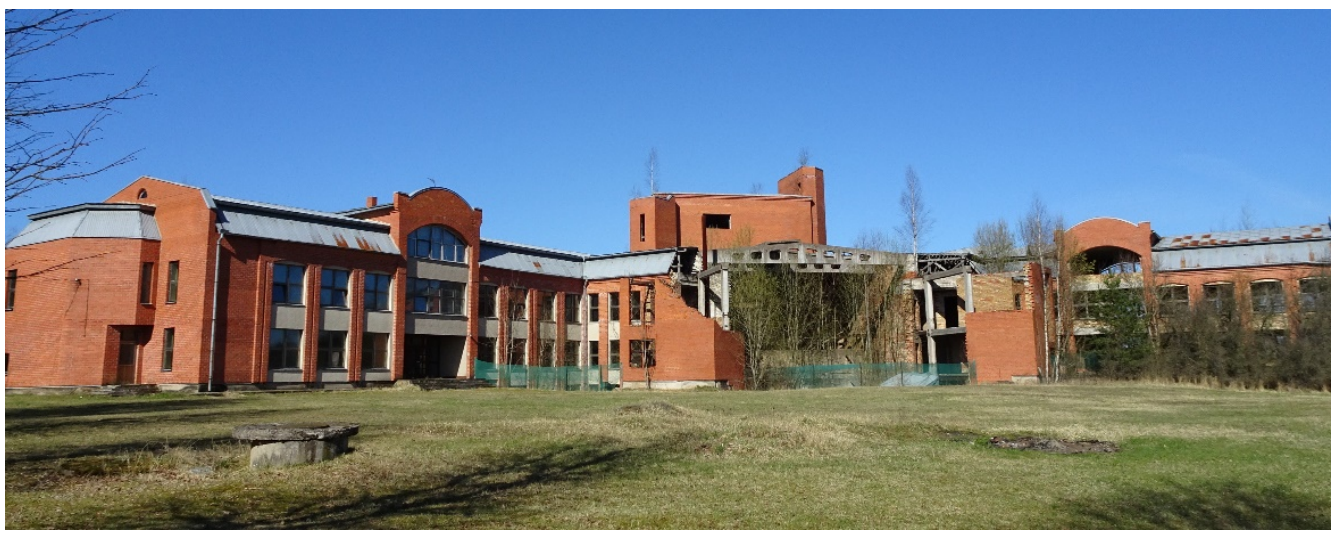

Fig. 7. The administrative-cultural building of Nigrande collective farm in Latvia, architect L. Tikmanis, designed in 1984-1986 but unfinished. Photo: Laura Ingerpuu, 2018.

Another threat that commonly concerns the Soviet time architecture today is the complete reconstruction of the buildings with new construction materials and installations which means that the original and authentic appearance will be lost. Casual and cheap reparations to adopt a former administrative-cultural centre for a new function have ruined the interior and exteriors of many buildings already [10, 13]. The reason why there still exist buildings with well-preserved authentic appearance lies paradoxically in the fact that the owners do not have enough resources to repair the building. For example, the administrative building of Eriškiai Kolkhoz in Lithuania, whose facades are repaired with contemporary inexpensive materials, but the interior has not been changed over the years. Therefore, there are exceptionally well-preserved interior design materials, elements and details. It also has to be admitted that due to the 
Soviet time specific construction materials and their poor quality, the authentic restoration is not easy or might be very expensive. As regards modernist architecture, it is a more philosophical question today in all the post-Soviet countries whether the Soviet time structures and fabrics should be restored authentically to preserve the history, but, in reality, the buildings from the 1960s till the 1990s are mainly fixed up with contemporary construction materials and processes which distort completely the original appearance [13].

\section{Conclusion}

It can be concluded that the Baltic States are facing rather similar challenges as regards the preservation and viability of the administrative-cultural buildings of collective farms. Lack of people in the countryside, scarce financial resources and poor Soviet time construction quality do not support the reuse of these edifices. The possibility that the administrative-cultural centres which are already in a poor technical condition will be renovated and reused in the future is minimal everywhere, especially in Latvia, where there are a number of unfinished buildings in rural settlements with very low population. Valuing and protecting the administrative-cultural centres on the state level varies from country to country. However, while on the experts' level the values have been recognised, public awareness of the importance of these buildings is fairly modest everywhere. Probably the most complicated is the current situation in Lithuania due to the controversial public attitude towards all the Soviet time heritage. Thus, it is essential not to ignore this part of the Baltic history in which the administrative-cultural buildings of collective farms have an essential place. To solve the socio-economic issues of the Baltic rural areas is a larger challenge, however, the general approach in rising awareness of the values of the administrative-cultural buildings of collective farms could already contribute into preservation of this Soviet-era architectural heritage.

\section{Acknowledgements}

I wish to thank Dr Marija Drèmaite from the University of Vilnius, Dr Agate Enina from the School of Architecture in Riga, Mr Algimantas Degutis and Mr Alfredas Jomantas from the Department of Cultural Heritage under the Lithuanian Ministry of Culture, Ms Alma Kaurāte from the Latvian National Heritage Inspection, and Dr Anneli Randla and Dr Epp Lankots from the Estonian Academy of Arts for useful guidance and friendly cooperation. I also thank all the other contributors who took their time to meet me and share their thoughts with me.

\section{Short resume}

Laura Ingerpuu is a $\mathrm{PhD}$ student of Cultural Heritage and Conservation in the Estonian Academy of Arts. Her main research field is architectural heritage from the second half of the $20^{\text {th }}$ century, particularly the socialist rural architecture in Estonia. She also works as a built heritage expert in the Estonian National Heritage Board.

\section{References}

1. KHRUSHCHEV, N. S. 1963. Khrushchev Speaks: Selected Speeches, Articles and Press Conferences, 1949-1961, (edited by Thomas P. Whitney), Ann Arbor, University of Michigan Press. 
2. COHEN, J.-L. 2011. The Future of Architecture. Since 1889. A Worldwide History, London, Phaidon.

3. DRĖMAITE், M. 2017. Baltic Modernism. Architecture and Housing in Soviet Lithuania, Berlin, DOM publishers.

4. RUDOVSKA, M. 2012. "Expired Monuments: Case Studies on Soviet-era Architecture in Latvia through the Kaleidoscope of Postcolonialism", Kunstiteaduslikke Uurimusi, vol. 21, $\mathrm{n}^{\circ}$ 3, January: 76-93. Retrieved from:

https://ktu.artun.ee/articles/2012_3_4/ktu_21_3_076-093_rudovska.pdf [available on 11 January 2019].

5. RUDOVSKA, M. 2014. "In the Shadows of Nostalgia. Marta Stana's Legacy in Latvia", in M. Drèmaitè, J. Reklaitè (eds.), Modernism: Between Nostalgia and Criticism, Vilnius, Vilnius University and Všl Architektūros fondas (Architecture[publication]fund), Retrieved from: http://leidiniu.archfondas.It/en/alf02/maija-rudovska-shadows-nostalgia-marta-stana's-legacy-latvia [available on 2 April 2018].

6. VIIRMA, V. 1983. "Keskusehooned ja klubid ainuprojektide järgi" [The Central Buildings and Clubs by the Original Design], Sotsialistlik põllumajandus, November 22: 28-30.

7. KALM, M. 2013. "Collective Farms of Soviet Estonia: Promoters of Architecture", in C. Caldenby, O. Wedebrunn (eds.). Survival of Modern from Cultural Centres to Planned Suburbs, Copenhagen, Royal Danish Academy of Fine Arts: 22-33.

8. PETRULIS, V. 2013. "Cultural Centres of Soviet Lithuania. Parts of Multi-Stage Cultural-Domestic Service System", in C. Caldenby, O. Wedebrunn (eds.). Op. cit:: 34-45.

9. STRAUTMANIS, I.A.; BUKA, O.M.; KRASTINŠ, J.A, et al. 1987. Архитектура Советской Латвии. Architecture of the Soviet Latvia, Moscow, Стройиздат [Stroyizdat].

10. ENINA, A.; KRASTINŠ, J. 2012. "Culture House - a Nucleus of a Collective Farm of Soviet Latvia", Architecture and Urban Planning, vol. 6: 43-50. DOI: https://doi.org/10.7250/aup.2012.007.

11. LEPPIK, H. 1980. Kolhoosiehitus Nõukogude Eestis [Collective farm construction in Soviet Estonia], Tallinn, Valgus.

12. JÄNES, L. 2017. "Eesti üks erilisemaid maju asub Raplas" [One of the Most Peculiar Buildings of Estonia is Situated in Rapla], Raplamaa Sõnumid, January 3. Retrieved from: https://xn--snumid-pxa.ee/artikkel/eesti-uks-erilisemaid-majuasub-raplas/ [available on 2 April 2018].

13. Interview with Dr Marija Drèmaitè, department of history, University of Vilnius, 7.10.2017, Vilnius. All of the information is in possession of the author.

14. DRĖMAITĖ, M; PETRULIS, V.; GRUNSKIS, T., et al. 2009. modernizmas.It. [Website]. Všl Architektūros fondas (Public Architecture [...] fund). Retrieved from: http://www.modernizmas.lt/ [available on 2 April 2018].

15. DEPARTMENT OF CULTURAL HERITAGE UNDER THE MINISTRY OF CULTURE. 2009. Kultūros Vertybių Registras - Juknaičiu gyvenvietè-parkas (code 33144) [Lithuanian Registry of Cultural Heritage. Cultural Heritage Registry: Juknaičic Sovhoz (code 33144)]. [Web page]. Retrieved from https://kvr.kpd.It/\#/static-heritage-search [available on 2 April 2018]. 
16. ARCHITECTURE OFFICE NRJA (ed.) 2014. Unwritten. Exhibition of Latvia at the $14^{\text {th }}$ International Architecture Exhibition - la Biennale di Venezia. Catalogue, Riga, Jelgavas Tipografija. Retrieved from https://issuu.com/nrja/docs/unwritten/19 [available on 11 January 2019].

17. Interview with Alma Kaurāte, Specialist in Cultural Heritage Policy of National Heritage Inspection. 18.05.2018, Riga. All of the information is in possession of the author.

18. Interview with Algimantas Degutis, Deputy Director of the Department of Cultural Heritage under the Lithuanian Ministry of Culture, 6.10.2017, Vilnius. All of the information is in possession of the author.

19. INGERPUU, L. 2015. Identification and Management of Soviet Time Rural Architectural Heritage (1944-1991) in Estonia: The Administrative Buildings of Collective Farms and Construction Offices, (Master Thesis of Master of Science in Conservation of Monuments and Sites), Leuven, Catholic University of Leuven.

20. MINKEVIČUS, J. K. 1987. Архитектура Советской Литвы. Architecture of the Soviet Lithuania. Moscow, Стройиздат [Stroyizdat].

21. VOLKOV, L. 1987. Архитектура Советской Эстонии. Architecture of the Soviet Estonia. Moscow, Стройиздат [Stroyizdat]. 